\title{
UPAYA GURU DALAM MENINGKATKAN KEMAMPUAN MOTORIK HALUS PESERTA DIDIK MELALUI KEGIATAN MEWARNAI
}

\author{
Ida Suidah \\ TK Pembina Dawuan Majalengka, Indonesia \\ idahsuidah@gmail.com
}

\begin{abstract}
This study aims to determine the efforts of teachers in improving the fine motor skills of students through coloring activities in kindergarten Pembina Dawnan District Majalengka District. Fine motor skills are very important to support further education. This research is a School Action Research conducted in 2 cycles. The subject of this research is TK Pembina Dawnan Subdistrict, Majalengka Regency with 36 children with the object of fine motor skills. Data collection techniques used are observation and documentation. Data analysis uses descriptive qualitative and quantitative. The results of observing fine motor skills before the average action percentage of $64.58 \%$ with BSH criteria, an increase of $3.65 \%$ in the first cycle are in the BSH criteria, in the second cycle an increase of $11.72 \%$ becomes Very Good Development. Based on these data it can be concluded that the fine motor skills of children have increased and achieved more than 75\% success indicators with Very Good Developing criteria. The success is inseparable from the learning steps, namely: (1) One class is divided into 3 groups consisting of 4-5 children (2) Each group gets 4-5 kinds of coloring that have been put in a container (3) The teacher gives examples of coloring activities (4) Deliver the agreed rules during the coloring activity and (5) The colored images are adjusted to the ongoing theme in kindergarten
\end{abstract}

Keywords: School Action Research, Teacher, Fine Motor Ability.

\section{ABSTRAK}

Penelitian ini bertujuan untuk mengetahui upaya guru dalam meningkatkan kemampuan motorik halus peserta didik melalui kegiatan mewarnai di TK Pembina Kecamatan Dawuan Kabupaten Majalengka. Kemampuan motorik halus sangat penting untuk mendukung jenjang pendidikan selanjutnya. Penelitian ini Penelitian Tindakan Sekolah yang dilaksanakan dalam 2 siklus. Subjek penelitian ini adalah TK Pembina Kecamatan Dawuan Kabupaten Majalengka berjumlah 36 anak dengan objek kemampuan motorik halus. Teknik pengumpulan data yang digunakan adalah observasi dan dokumentasi. Analisis data menggunakan deskriptif kualitatif dan kuantitatif. Hasil observasi kemampuan motorik halus sebelum tindakan rata-rata persentase sebesar $64,58 \%$ dengan kriteria $\mathrm{BSH}$, mengalami peningkatan sebesar 3,65\% pada siklus I berada pada kriteria BSH, pada siklus II mengalami peningkatan sebesar $11,72 \%$ menjadi Berkembang Sangat Baik. Berdasarkan data tersebut dapat disimpulkan bahwa kemampuan motorik halus anak mengalami peningkatan dan mencapai indikator keberhasilan lebih dari 75\% dengan kriteria Berkembang Sangat Baik. Keberhasilan tersebut tidak terlepas dari langkah-langkah pembelajaran yaitu: (1) Satu kelas dibagi menjadi 3 kelompok terdiri dari 4-5 anak (2) Tiap kelompok mendapatkan 4-5 macam pewarna yang sudah diletakkan dalam wadah (3) Guru memberikan contoh kegiatan mewarnai yang akan dilakukan (4) Menyampaikan aturan yang telah disepakati selama kegiatan mewarnai dan (5) Gambar yang diwarnai disesuaikan dengan tema yang sedang berlangsung di TK.

Kata Kunci: Penelitian Tindakan Sekolah, Guru, Kemampuan Motorik Halus.

Submitted November 2, 2019 | Revised November 15, 2019 | Accepted November 16, 2019

\section{Pendahuluan}

Berdasarkan Undang-undang Nomor 20 Tahun 2003 tentang Sistem Pendidikan Nasional Pasal 1 angka 14 menyatakan bahwa Pendidikan Anak Usia Dini (PAUD) adalah suatu upaya pembinaan yang ditujukan kepada anak sejak lahir sampai dengan usia enam tahun yang dilakukan melalui pemberian rangsangan pendidikan untuk membantu pertumbuhan dan perkembangan jasmani serta rohani agar anak memiliki kesiapan dalam memasuki pendidikan 
selanjutnya. Oleh karena itu, terdapat beberapa layanan pendidikan yang didirikan oleh pemerintah maupun masyarakat untuk anak usia 0-6 tahun yang bertujuan mengembangkan aspek-aspek perkembangan yang dimiliki anak (Sujiono, 2008).

Berdasarkan Peranturan Menteri Pendidikan Nasional No 58 Tahun 2009 menyatakan bahwa jenis layanan PAUD dapat dilaksanakan dalam jalur pendidikan formal maupun nonformal. Jalur pendidikan formal yaitu Taman Kanak-Kanak (TK) atau Raudhatul Atfal (RA) dan bentuk lain yang sederajat untuk anak usia 4-6 tahun. Jalur pendidikan nonformal dapat berbentuk Taman Pengasuhan Anak (TPA) untuk usia 0-2 tahun serta Kelompok Bermain (KB) untuk usia 2-4 tahun atau bentuk lain yang sederajat. Taman Kanak-kanak tergolong ke dalam jalur pendidikan formal yaitu pendidikan yang diselenggarakan untuk anak usia 4-6 tahun. Anak usia 4-6 tahun termasuk dalam usia keemasan (golden age), pada usia ini anak mempunyai daya serap yang luar biasa apabila terus diberikan stimulasi sesuai tahap perkembangannya sehingga pada usia ini lima aspek perkembangan anak harus dioptimalkan semaksimal mungkin. Kelima aspek perkembangan itu adalah aspek kognitif, bahasa, fisik motorik, nilai moral agama dan sosial emosional.

Kemampuan fisik motorik merupakan kemampuan yang sangat penting untuk menunjang kelangsungan hidup sehari-hari oleh karena itu kemampuan fisik motorik anak usia dini harus dikembangkan sejak usia dini baik kemampuan motorik kasar maupun kemampuan motorik halus. Menurut artikel yang ditulis (Indraswari, 2012: 2) motorik kasar memerlukan koordinasi kelompok otot- otot tertentu anak yang dapat membuat mereka melompat, memanjat, berlari, menaiki sepeda. Sedangkan menurut artikel yang ditulis oleh (Marliza, 2012: 1) perkembangan gerakan motorik halus anak taman kanak-kanak ditekankan pada koordinasi gerakan motorik halus dalam hal ini berkaitan dengan kegiatan meletakkan atau memegang suatu objek dengan menggunakan jari tangan.

Stimulasi perkembangan motorik halus yang bertujuan melatih keterampilan jari-jemari anak untuk persiapan menulis seperti menggunting, menjiplak, memotong, menggambar, mewarnai, menempel, bermain play dough dan meronce perlu diberikan kepada anak taman kanakkanak agar kemampuan motorik halusnya dapat berkembang dengan baik (Noorlaila, 2017: 44). Penelitian ini akan membahas mengenai perkembangan motorik halus yaitu bagaimana meningkatkan kemampuan motorik halus melalui kegiatan mewarnai yang merupakan salah satu alternatif kegiatan pembelajaran yang dapat dilakukan oleh guru di sekolah untuk mengembangkan kemampuan motorik halus khususnya anak kelompok B yaitu usia 5-6 tahun.

Perkembangan motorik halus anak usia dini akan berkembang setelah perkembangan motorik kasar anak berkembang terlebih dahulu, ketika usia- usia awal yaitu usia satu atau usia dua tahun kemampuan motorik kasar yang berkembang dengan pesat Sukmadinata, 2010: 73). Mulai usia 3 tahun barulah kemampuan motorik halus anak akan berkembang dengan pesat, anak mulai tertarik untuk memegang pens walaupun posisi jari-jarinya masih dekat dengan mata pensil selain itu anak juga masih kaku dalam melakukan gerakan tangan untuk menulis (Kartikasari, 2012).

Berdasarkan pengamatan yang dilakukan di TK Pembina Kecamatan Dawuan Kabupaten Majalengka mengenai kemampuan motorik halus ketika kegiatan mewarnai, yaitu kemampuan menggerakkan jari jemari dan pergelangan tangan yang kurang optimal karena anakanak kurang antusias ketika melaksanakan kegiatan mewarnai. Ketika pelaksanaan observasi 
terdapat 10 anak yang belum mencapai kriteria Berkambang Sangat Baik (BSB) dengan persentase sebesar 63,5\% dan yang sudah mencapai kriteria BSB sebanyak 6 anak dengan persentase sebesar 37,5\%. Sesuai hasil observasi tersebut maka sangat perlu untuk meningkatkan kemampuan motorik halus anak agar maksimal dan mencapai kriteria Berkembang Sangat Baik (BSB).

Tanya jawab antara Guru dan anak terjadi ketika pelaksanaan observasi, Guru bertanya: "Mengapa mewarnai gambarnya seperti itu mas?",. Anak menjawab: "Bosan, malas, capek" dengan kegiatan mewarnai yang dilakukan karena alat yang digunakan untuk mewarnai adalah krayon atau spidol. Oleh karena itu, perlu dipersiapkan kegiatan mewarnai menggunakan sarana serta alat yang bervariasi agar kemampuan motorik halus anak dalam menggerakkan jarijemari dan pergelangan tangan ketika kegiatan mewarnai dapat berkembang secara maksimal serta menarik minat anak agar tidak merasa bosan.

Berdasarkan pelaksanaan observasi dan informasi yang didapatkan dari guru, anak tidak bermasalah terkait kegiatan motorik halus lain seperti kegiatan menempel, menjiplak, menggunting, meronce dan bermain balok. Selanjutnya, anak sangat antusias dalam kegiatan menempel, menjiplak, menggunting, meronce dan bermain balok. Hal tersebut dikarenakan kegiatan menempel, menjiplak, menggunting, meronce dan bermain balok tidak terlalu sering dilakukan dan pelaksanaannya menggunakan media yang bervariasi. Oleh karena itu, tidak menimbulkan kejenuhan dan perkembangan motorik halus anak dapat berkembang maksimal. Mengemas kegiatan yang bertujuan untuk mengembangkan motorik halus melalui media yang bervariasi sangat penting dilakukan. Selain itu, strategi yang digunakan ketika melaksanakan kegiatan tersebut juga perlu dipersiapkan semenarik mungkin untuk menarik antusiasme anak dan memberikan stimulasi yang maksimal.

Sesuai pengamatan yang sudah dilakukan sebelumnya dapat disimpulkan bahwa di TK Pembina Kecamatan Dawuan Kabupaten Majalengka terdapat masalah ketika kegiatan pembelajaran. Masalah yang dimaksud terletak pada kemampuan motorik halus yang berkembang kurang maksimal karena stimulasi yang diberikan kepada anak kurang bervariasi sehingga kemampuan anak untuk bereksplorasi menggunakan jari-jemari serta pergelangan tangan juga kurang. Stimulasi motorik halus yang kurang bervariasi terletak pada penggunaan krayon dan spidol untuk kegiatan mewarnai yang terlalu sering dilakukan.

Anak usia 5-6 tahun koordinasi gerakan motorik halus berkembang dengan pesat menurut tahap perkembangannya anak mampu mengkoordinasikan gerakan mata dengan gerakan tangan, lengan dan tubuh secara bersamaan, hal ini bisa dilihat ketika anak menggambar ataupun mewarnai (Eileen, 2010). Jadi, kegiatan mewarnai sangat penting diberikan pada anak usia 5-6 tahun yang sedang duduk di TK Pembina Kecamatan Dawuan Kabupaten Majalengka. Sangat berbahaya apabila pada usia ini ketika diberikan kegiatan mewarnai anak mengalami kejenuhan dan kurang antusias.

Solusi yang diberikan oleh penulis untuk mengatasi masalah yang terdapat di TK Pembina Kecamatan Dawuan Kabupaten Majalengka adalah dengan memberikan variasi kegiatan mewarnai gambar menggunakan alat yang beragam dengan memperhatikan pengaturan intensitas penggunaan yang tidak terlalu sering. Alat yang digunakan untuk kegiatan mewarnai adalah pelepah pisang, pelepah daun pepaya dan cotton bud. 


\section{Metode Penelitian}

Penelitian ini merupakan Penelitian Tindakan Sekolah yang dilakukan secara kolaborasi. Penelitian Tindakan Sekolah berdasarkan pendapat Sanjaya (2011: 26) adalah proses pengkajian masalah pembelajaran di dalam kelas melalui refleksi diri dalam upaya untuk memecahkan masalah tersebut dengan cara melakukan tindakan yang terencana dalam situasi nyata serta menganalisis setiap pengaruh dari perlakuan tersebut. Pendapat tersebut sesuai pendapat yang disampaikan oleh Kasbolah (1998: 15), bahwa Penelitian Tindakan Sekolah merupakan penelitian tindakan dalam bidang pendidikan yang dilaksananakan dalam kawasan kelas dengan tujuan untuk memperbaiki dan atau meningkatkan kualitas pembelajaran.

Penelitian Tindakan Sekolah secara kolaborasi dilaksanakan dengan kerjasama atau kolaborasi yang dilakukan antara peneliti dan guru TK Pembina Kecamatan Dawuan Kabupaten Majalengka. Pembelajaran motorik halus melalui kegiatan mewarnai yang dilakukan disampaikan oleh Guru dan peneliti secara bergantian. Waktu Penelitian dilaksanakan dalam siklus-siklus yang tidak dapat ditentukan berapa pertemuan yang harus dilakukan. Tempat Penelitian dilaksanakan di TK Pembina Kecamatan Dawuan Kabupaten Majalengka. Pemilihan lokasi ini dilakukan karena di kelas tersebut terdapat masalah pada kemampuan motorik halus anak berkaitan dengan kemampuan motorik halus. Ada pun subjek dalam penelitian ini adalah anak TK Pembina Kecamatan Dawuan Kabupaten Majalengka, yang berjumlah 36 anak. Objek dalam penelitian ini adalah kemampuan motorik halus.

Banyak model Penelitian Tindakan Sekolah yang dapat diterapkan, tetapi dalam penelitian ini menggunakan model Kemmis dan McTaggart di mana dalam perencanaannya menggunakan siklus sistem spiral yang di dalamnya terdiri dari empat komponen, yaitu rencana, tindakan dan observasi serta refleksi (Sujati, 2000: 23).

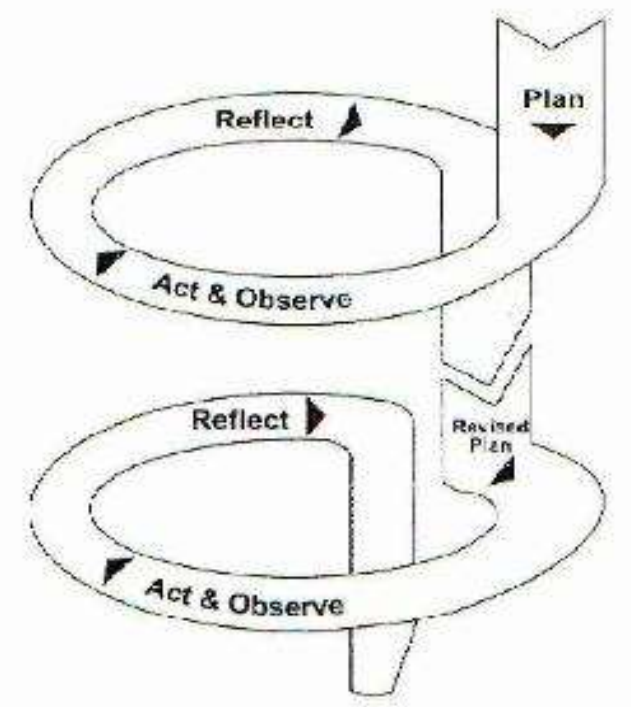

Gambar 2. Model kemmis dan Mc Taggart (Sujati, 2000: 23).

Dari gambar 1 di atas maka, penelitian tindakan yang akan dilakukan dapat diuraikan sebagai berikut: 
1. Perencanaan (Plan)

Melakukan observasi terhadap situasi atau kemampuan motorik halus anak sebelum dilakukan tindakan, membuat Rencana Kegiatan Harian terlebih dahulu dengan berdiskusi bersama guru kelas (kolaborator), membuat media yang digunakan untuk kegiatan pembelajaran serta mempersiapkan peralatan yang dibutuhkan bersama kolaborator, mempersiapkan lembar observasi yang digunakan untuk mengambil data serta melakukan penilaian dan evaluasi, melakukan setting atau penataan ruang kelas yang mendukung kegiatan pembelajaran.

2. Pelaksanaan (Act) dan Observasi (Observe)

Pelaksanaan dilakukan sesuai dengan perencanaan yang telah dibuat guru kelas dengan peneliti. Pelaksanaan penelitan dilakukan secara fleksibel yaitu bisa berubah sesuai dengan situasi dan kondisi yang ada di lapangan. Guru kelas sebagai kolaborator melaksanakan tindakan yang sudah direncanakan sesuai RKH sedangkan peneliti mengamati proses pembelajaran yang berlangsung.

3. Refleksi (Reflect)

Refleksi dilakukan pada setiap akhir siklus untuk mengetahui apakah kegiatan mewarnai yang diberikan sudah sesuai harapan atau belum serta digunakan peneliti dan kolaborator dalam melakukan evaluasi tentang perlu tidaknya melakukan siklus selanjutnya. Selain itu, melalui refleksi dapat melakukan analisis data pada lembar observasi yang telah diisi oleh peneliti dan kolaborator serta melakukan penilaian untuk menyusun rencana perbaikan yang akan dilakukan (Arikunto, 2010).

\section{Hasil dan Pembahasan}

Penelitian tindakan yang dilakukan untuk meningkatkan kemampuan motorik halus anak melalui kegiatan mewarnai telah dilaksanakan di TK Pembina Kecamatan Dawuan Kabupaten Majalengka selama 2 siklus menunjukkan adanya peningkatan serta keberhasilan. Berikut ini merupakan rata-rata prosentase kemampuan motorik halus anak dari sebelum tindakan, pelaksanaan siklus I dan siklus II.

Tabel 6

Persentase Peningkatan Kemampuan Motorik Halus Anak

\begin{tabular}{ccccc}
\hline No & Indikator & $\begin{array}{c}\text { Persentase } \\
(\%) \text { Sebelum } \\
\text { Tindakan }\end{array}$ & $\begin{array}{c}\text { Persentase } \\
(\%) \text { Siklus I }\end{array}$ & $\begin{array}{c}\text { Persentase } \\
(\%) \text { Siklus II }\end{array}$ \\
\hline 1. & Memegang $\quad$ Alat Mewarnai & & & \\
2. $\begin{array}{l}\text { Menggerakkan Pergelangan } \\
\text { Tangan }\end{array}$ & $64,58 \%$ & $68,23 \%$ & $79,95 \%$ \\
3. Mewarnai & Dengan Rapi & $\cdot$ & & \\
\hline
\end{tabular}

Berdasarkan tabel 6 di atas dapat diketahui adanya peningkatan dari data yang diperoleh sebelum tindakan dan sesudah dilakukan tindakan pada siklus I dan siklus II. Persentase kemampuan motorik halus anak kelompok TK Pembina Kecamatan Dawuan Kabupaten Majalengka sebelum tindakan sebesar $64,58 \%$, mengalami peningkatan pada pelaksanaan tindakan 
siklus I menjadi 68,23\% dan peningkatan signifikan terjadi pada pelaksanaan tindakan siklus II menjadi 79,95\%.

Berdasarkan analisis yang dilakukan oleh peneliti kemampuan motorik halus anak mengalami peningkatan setelah pelaksanaan kegiatan mewarnai gambar dilakukan menggunakan cotton bud dan pewarna makanan karena kegiatan mewarnai jarang dilakukan di TK Pembina Kecamatan Dawuan Kabupaten Majalengka sehingga menimbulkan antusiasme yang tinggi dari anak dan stimulasi yang diberikan kepada anak dapat dilakukan secara maksimal karena stimulasi motorik halus yang diberikan menggunakan beberapa variasi.

Kegiatan mewarnai sangat tepat untuk mengembangkan kemampuan motorik halus anak TK Pembina Kecamatan Dawuan Kabupaten Majalengka karena melalui kegiatan mewarnai anak belajar tentang kemampuan awal menulis yaitu dari kemampuan memegang alat mewarnai, menggerakkan pergelangan tangan dan koordinasi mata tangan yang sangat berguna untuk jenjang pendidikan selanjutnya. Oleh karena itu, menerapkan kegiatan mewarnai sangat tepat.

Hal tersebut sesuai dengan pendapat Pamadhi (2011: 7.4) bahwa anak-anak sangat suka memberi warna melalui berbagai media baik sangat menggambar atau meletakkan warna saat mengisi bidang-bidang gambar yang harus diberi pewarna. Ketika anak-anak senang atau suka melakukan kegiatan maka tujuan pemberian stimulasi dapat maksimal tercapai.

Kegiatan mewarnai yang dilaksanakan pada siklus I, menggunakan 3 alat mewarnai yang berbeda yaitu pelepah pisang, pelepah daun pepaya dan cotton bud hasilnya banyak anak yang mengalami kesulitan serta mengalami penurunan persentase dari pra tindakan. Kegiatan mewarnai pada siklus II dilakukan menggunakan 1 alat mewarnai saja yaitu cotton bud hasilnya kemampuan motorik halus anak dalam memegang alat mewarnai, menggerakkan pergelangan tangan dan mewarnai secara rapi dapat berkembang sangat baik dan sesuai indikator keberhasilan yang telah ditetapkan. Oleh karena itu, kegiatan mewarnai yang dilakukan untuk anak kelompok B dengan usia 5-6 tahun belum bisa dilakukan dengan 3 alat mewarnai sekaligus, tetapi baru menggunakan 1 alat mewarnai saja.

Berikut ini merupakan analisis perkembangan motorik halus anak dari pra tindakan, pelaksanaan siklus I dan pelaksanaan siklus II: Kemampuan motorik halus anak ketika pra tindakan mencapai kriteria BSH, pada siklus I meningkat menjadi BSB dan pada siklus II tetap pada kriteria BSB ada sebanyak 2 anak yaitu Ahm dan Ibn. Hal tersebut menunjukkan bahwa ketika pra tindakan, kegiatan mewarnai dilakukan menggunakan krayon sehingga anak-anak sudah terbiasa dan mencapai kriteria BSH. Ketika siklus I kegiatan mewarnai dilakukan menggunakan pelepah pisang, pelepah daun pepaya dan cotton bud, anak-anak bisa mencapai kriteria maksimal yaitu BSB. Begitu juga pada pelaksanaan kegiatan mewarnai pada siklus II yang menggunakan cotton bud anak-anak tetap mencapai kriteria BSB. Sesuai pernyataan tersebut maka kemampuan motorik halus anak dalam memegang alat mewarnai, menggerakkan pergelangan tangan dan mewarnai dengan rapi dapat berkembang maksimal setelah mendapatkan stimulasi yang bervariasi pada siklus I dan II.

Kemampuan motorik halus anak ketika pra tindakan mencapai kriteria BSH, pada siklus I tetap pada kriteria BSH dan pada siklus II meningkat menjadi BSB ada sebanyak 4 anak. Pernyataan tersebut menujukkan bahwa ketika pelaksanaan siklus I yaitu mewarnai menggunakan pelepah pisang, pelepah daun pepaya dan cotton bud anak-anak merasa kesulitan serta 
membutuhkan penyesuaian yang lebih lama ketika stimulasi motorik halus melalui kegiatan mewarnai dilakukan selain menggunakan krayon. Setelah pelaksanaan siklus II kegiatan mewarnai dilakukan menggunakan cotton bud saja barulah kemampuan motorik halus anak dalam memegang alat mewarnai, menggerakkan pergelangan tangan dan mewarnai dengan rapi dapat berkembang maksimal menjadi BSB.

Kemampuan motorik halus anak ketika pra tindakan sudah mencapai kriteria BSB, pada siklus I stabil pada kriteria BSB dan pada siklus II tetap stabil pada kriteria BSB ada sebanyak 5 anak. Pernyataan tersebut menunjukkan bahwa kelima anak tersebut kemampuan motorik halusnya dalam memegang alat mewarnai, menggerakkan pergelangan tangan dan mewarnai dengan rapi dapat berkembang maksimal walaupun stimulasi yang diberikan menggunakan variasi kegiatan mewarnai yang berbeda. Jadi perkembangan kelima anak tesebut masuk dalam kategori sangat baik.

Sesuai pernyataan tersebut berarti ketika kegiatan mewarnai menggunakan krayon dilakukan kemampuan yang ditunjukkan kurang maksimal, begitu juga ketika pelaksanaan kegiatan mewarnai mengggunakan pelepah pisang, pelepah daun pepaya dan cotton bud pada siklus I masih memerlukan penyesuaian karena kegiatan mewarnai tersebut termasuk hal yang baru dan ketika pelaksanaan siklus II kegiatan mewarnai dilakukan menggunakan cotton bud kemampuan motorik halus dalam memegang alat mewarnai, menggerakkan pergelangan tangan dan mewarnai dengan rapi dapat berkembang maksimal karena sudah mulai terbiasa dengan kegiatan mewarnai yang dilakukan.

Indikator keberhasilan yang tercapai serta peningkatan persentase yang terjadi dari sebelum tindakan ke siklus I dan dilanjutkan pada siklus II dikarenakan kegiatan mewarnai dilakukan selama 6 kali pertemuan dimulai dari kegiatan mewarnai yang mudah ke sulit. Selain itu, kegiatan mewarnai dilaksanakan secara berulang-ulang untuk mencapai hasil yang maksimal dan disesuaikan dengan perkembangan anak. Hal tersebut sesuai pendapat Dirjen Manajemen Pendidikan Dasar dan Menegah (2007: 11) yang menyatakan bahwa pengembangan motorik halus dilakukan secara bertahap serta berulang-ulang sesuai kemampuan anak.

Penelitian Tindakan Sekolah yang dilakukan untuk meningkatkan kemampuan motorik halus melalui kegiatan mewarnai dilaksanakan dengan subjek penelitian sebanyak 36 anak, sehingga Guru dan peneliti mengalami kesulitan dalam melakukan penilaian terhadap kemampuan motorik halus. Selain itu, kesulitan juga dialami ketika mengkondisikan anak untuk berkonsentrasi.

\section{Kesimpulan}

Berdasarkan hasil penelitian dan pembahasan, maka peneliti menarik kesimpulan bahwa kegiatan mewarnai dapat meningkatkan kemampuan motorik halus anak TK Pembina Kecamatan Dawuan Kabupaten Majalengka. Peningkatan tersebut dapat dilihat dari adanya peningkatan persentase dari sebelum tindakan dan setelah pelaksanaan tindakan pada siklus I dan siklus II. Pelaksanaan tindakan pada siklus I menggunakan 3 alat mewarnai yang berbeda dan anak-anak merasa kesulitan karena 3 stimulasi diberikan sekaligus sehingga peningkatan persentase yang ditunjukkan dari pra tindakan ke siklus I sebesar 3,65\% kemudian peningkatan persentase yang cukup signifikan ditunjukkan pada pelaksanaan siklus II menjadi 11,72\% dikarenakan kegiatan 
mewarnai dilakukan menggunakan 1 alat mewarnai saja sehingga stimulasi yang diberikan kepada anak bisa tuntas dan anak tidak mengalami kesulitan.

Keberhasilan tersebut tidak terlepas dari langkah-langkah pembelajaran motorik halus melalui kegiatan mewarnai yang dilakukan ketika pelaksanaan Penelitian Tindakan Sekolah (PTK) di TK Pembina Kecamatan Dawuan Kabupaten Majalengka yaitu: (1) Satu kelas dibagi menjadi 3 kelompok yang terdiri dari 12 anak (2) Tiap kelompok mendapatkan 4-5 macam pewarna yang sudah diletakkan pada wadah (3) Guru memberikan contoh kegiatan mewarnai yang akan dilakukan (4) Menyampaikan aturan yang telah disepakati selama kegiatan mewarnai dilakukan dan (5) Gambar yang diwarnai disesuaikan dengan tema yang sedang berlangsung di TK.

\section{Daftar Pustaka}

Arikunto, S. (2010). Penelitian Tindakan Sekolah. Yogyakarta: Aditya Media.

Departemen Pendidikan Nasional. (2007). Pedoman Pembelajaran Bidang Pengembangan Fisik Motorik di Taman Kanak-Kanak. Jakarta: Dirjen Manajemen Pendidikan Dasar dan Menengah.

Eileen, K.A. \& Marotz, L.R. (2010). Profil Perkembangan Anak Prakelabiran Hingga Usia 12 Tabun. Penerjemah: Valentino. Jakarta: PT Indeks.

Hurlock, Elizabeth B. (1978). Perkembangan Anak. Penerjemah: Meitasari Tjandra dan Muslichah Zarkasih. Jakarta: Erlangga.

Indraswari, L. (2012). Peningkatan Perkembangan Motorik Halus Anak Usia Dini Melalaui Kegiatan Mozaik Di Taman Kanak-Kanak Pembina Agam. Jurnal Pesona PAUD (Vol.1.No.1). Hlm.2.Kasbolah, K. (1998). Penelitian Tindakan Sekolah. Jakarta: Departemen Pendidikan dan Kebudayaan Direktorat Jenderal Pendidikan Tinggi.

Kartikasari, A. (2012). Meningkatkan Kemampuan Motorik Halus Anak Usia 5 - 6 Tahun Melalui Kegiatan Mewarnai Gambar di TK Al-Iqra' Mataram Tahun Ajaran 2012/2013. Jurnal Pesona PAUD (Vol.1.No.1). Hlm 1

Mansur. (2005). Pendidikan Anak Usia Dini Dalam Islam. Yogyakarta: Pustaka pelajar.

Marliza. (2012). Peningkatan Kemampuan Motorik Halus Anak Melalui Permainan Melukis Dengan Kuas Taman Kanak-Kanak Pasaman Barat. Jurnal Pesona PAUD. (Vol.1.No.1). Hlm.1.

Morrison, S G. (2012). Buku Dasar-dasar Pendidikan Anak Usia Dini. Penerjemah: Suci Romadhona dan Apri Widiastuti. Jakarta: PT Indeks.

Noorlaila. (2010). Buku Panduan Lengkap Mengajar PAUD. Yogyakarta: Pinus Book Publisher.

Pamadhi, H. (2011). Seni Keterampilan Anak. Jakarta: Universitas Terbuka.

Riduwan. (2011). Belajar Mudah Penelitian. Bandung: Alfabeta. 
Sanjaya. (2010). Penelitian Tindakan Sekolah. Jakarta: Kencana.

Santrock, John W. (2007). Perkembangan Anak. Penerjemah: Mila Rachmawati S.Psi. dan Ama Kuswanti. Jakarta: Erlangga.

Sujati. (2000). Penelitian Tindakan Sekolah. Yogyakarta: Universitas Negeri Yogyakarta.

Sujiono, B. (2008). Metode Pengembangan Fisik . Jakarta: Universitas Terbuka.

Sukmadinata, NS.. (2010). Metode Penelitian Pendidikan. Bandung: Remaja Rosdakarya.

Syamsudin A.R. \& Vismaia S. D. (2006). Metode Penelitian Pendidikan Bahasa. Bandung: Remaja Rosdakarya. 